\title{
Hemşirelik Öğrencilerinin El Hijyeni Ve Eldiven Kullanma Alışkanlıklarının \\ Belirlenmesi*
}

\author{
Determination of Nursing Students' Hand Hygiene and Glove Use Habits
}

Erhan Şensoy

'Dr. Öğr. Üyesi, Karamanoğlu Mehmetbey Üniversitesi Sağlık Bilimleri Fakültesi Ebelik Bölümü https://orcid.org/0000-0003-2989-459X

öz

Amaç: Çalışmanın amacı; bir devlet üniversitesinin sağlık bilimleri fakültesi hemşirelik bölümü öğrencilerinin el hijyeni, eldiven kullanımına yönelik görüşleri ve eldiven kullanma alışkanlıklarının belirlenmesidir.

Yöntem: Çalışmanın evreni 116 kadın $(\% 82,3)$ ve 25 erkek $(\% 17,7) 141$ öğrenciden oluşmaktadır. Öğrencilerin yaş ortalaması $20,43 \pm 1,39$ 'dur. Anket formuyla toplanan verilerin analizi; frekans ve betimsel istatiksel analiz teknikleri ve Ki-kare testiyle değerlendirilmiştir.

Bulgular: Katılımcıların eldiven giymeden önce el yıkanma oranı \%86,5 ve eldiven çıkarıldıktan sonra el yıkanma oranı \%96,5 olarak belirlenmiştir. Hastayı ve kendimizi korumada güvenli yöntemler; el yıkama, eldiven kullanma, alkol bazlı el antiseptiği kullanma olarak saptanmıştır. Eldiven kullanımına yönelik bazı önermelere katılımla; cinsiyet değişkeni arasında kuvvetli ilişki belirlenmiştir.

Sonuç: Öğrencilerimizin eldiven kullanımına yönelik görüşlerinin olumlu ve alışkanlıklarının yeterli olduğu belirlenmiştir. Bununla birlikte; tek kullanımlık eldivenlerin tekrar kullanabileceği, yıkanabileceği, eldiven kullanmanın el yıkamanın yerini tutabileceği gibi yanlış bilgilere sahip öğrencilerin olması önemli olarak değerlendirilmiştir. Olumlu kazanımların davranışa dönüşmesi için eldiven kullanımına yönelik detaylı eğitimlere birinci sınıfta başlanarak aralıksız devam edilmesi önerilir.

Anahtar Kelimeler: Bulaşıcı hastalık, Eldiven kullanımı, Hastane enfeksiyonu, Hemşirelik öğrencisi, Hijyen eğitimi

\section{ABSTRACT}

Aim: The aim of the study; It is the determination of hand hygiene, glove use and glove wearing habits of the students of the faculty of health sciences of a state university.

Material and Methods: The universe of the study consisted of; 116 women (82,3\%) and 25 men (17,7\%) 141 students. The average age of the students is $20,43 \pm 1,39$. Analysis of data collected by questionnaire form; frequency and descriptive statistical analysis techniques and Chi-square test.

Results: It was determined that the hand washing rate of the participants was $86,5 \%$ before wearing gloves, and $96,5 \%$ after glove removal. Safe methods to protect the patient and ourselves; hand washing, using gloves, using alcohol-based hand sanitizer. Participating in some suggestions for the use of gloves; A strong relationship was found between the gender variable.

Conclusion: It was determined that our students' opinions about the use of gloves were positive and their habits were sufficient. However; having students with misinformation such as that disposable gloves can be reused, washed, and using gloves can replace hand washing was considered important. In order to transform positive gains into behavior, it is recommended that detailed training on the use of gloves should be started in the first grade and continued without interruption.

Keywords: Infectious disease, Hygiene training, Hospital infection, Nursing student, Use of gloves

*Lokman Hekim Dergisi, 2021; 11 (2): 353-363

DOI: $10.31020 /$ mutftd.876950

e-ISSN: 1309-8004, ISSN 1309-761X

Geliş Tarihi - Received: 08 Şubat 2021; Kabul Tarihi - Accepted: 27 Nisan 2021

iletişim - Correspondence Author: Erhan Şensoy <erhansensoy@kmu.edu.tr>

Etik Onay: Karamanoğlu Mehmetbey Üniversitesi Sağlık Bilimleri Fakültesi Girişimsel Olmayan Klinik Araştırmalar Etik Kurulu (Karar No: 06-16, Karar tarihi: 30/05/2018) 


\section{Giriş}

Hastanede başka sağlık sorunlarının tedavi sürecinde gelişen enfeksiyonlara "Hastane Enfeksiyonu" adı verilir. Hastaneye yatıştan yaklaşık 48-72 saat ve taburcu olduktan sonra 10 gün içinde ortaya çıkarlar ve hastada strese, yaşam kalitesinin azalmasına, hastanede yatış süresinin, tedavi maliyetlerinin, morbidite ve mortalite oranlarının artmasına yol açarlar. ${ }^{1-3}$ Hastane enfeksiyonuna yol açan mikroorganizmalar; taburcu edilen hastalar, sağlık çalışanları veya hasta ziyaretçileri yoluyla topluma yayılabileceği için hastane enfeksiyonları, ciddi bir toplumsal sağılık sorunu olarak değerlendirilir., ${ }^{2,3}$ Hastane enfeksiyonlarında; hastayla ve hastaneyle ilgili faktörler etkilidir. Hastayla ilgili faktörler; yaş, metabolik hastalıklar, hastanın kullandığı ilaçlar, beslenme ve bağışıkıı durumudur. ${ }^{4,5}$ Hastaneyle ilgili faktörler; sağlık çalışanı sayısınının ve bilgilerinin yetersiz olması, çalışanlar arasında el yıkama ve eldiven kullanımı gibi izolasyon yöntemlerine uyulmamasıdır. ${ }^{4,5}$

Günümüzde sağlık çalışanları tarafından, hastaları ve sağlık çalışanlarını kan-vücut sıvılarıyla bulaşan enfeksiyonlardan korumak amacıyla uygulanan Evrensel Yöntemler; 1987 yılında "Hastalık Önleme ve Kontrol Merkezi" (Centers for Disease Control and Prevention, CDC) tarafından önerilmiştir. Evrensel Yöntemler kapsamındaki birincil grup önlemler; ellerin yıkanması, el hijyeninin sağlanması ve eldiven kullanımıdır..$^{4-6} \mathrm{EI}$ yıkama, hastane enfeksiyonlarının önlenmesinde en etkili ve kolay uygulama olmakla birlikte, zaman alması nedeniyle sağlık çalışanları tarafından en az gerçekleştirilen uygulamadır. ${ }^{7}$ Günüzmüzde sık kullanılan izolasyon yöntemlerinden olan eldiven kullanımı 1980'li yıllarda görülen AIDS pandemisinin ardından Dünya genelinde yaygınlaşmış ve başta ülkemiz olmak üzere pek çok ülkede zorunlu hale gelmiştir. ${ }^{8,9}$ Eldiven, kullanım amacına uygun seçilmeli; ele uygun büyüklükte olmalı ve lateks alerjisi olanlar için pudurasız eldivenler tercih edilmelidir. ${ }^{10,11}$ Eldiven kullanma konusunda sağlık çalışanları arasında en sık yapılan yanlış uygulamalar; aynı eldivenle birden çok hastaya ya da aynı hastanın farklı bölgesine temas etmek, eldivenin uzun süre elde kalması sonucu elin terlemesi, eldiven çıkarıldıktan sonra ellerin yıkanmaması, bir hastadan diğer hastaya geçişte eldivenin değiştirilmemesi, bazı uygulamalarda birden fazla eldiven giyilmesi ve eldivenin gereksiz kullanımıdır. ${ }^{12}$

Hemşirelik öğrencilerinin el hijyeni sağlama ve eldiven kullanımına yönelik bilgi, tutum ve kullanım alışkanlıklarının belirlenmesi; sağlık çalışanı adaylarının sık olarak yaptıkları yanlış uygulamaların tespitine, bunların düzeltilmesi için çözüm yollarının ortaya konmasına, bu yolla bilgi düzeylerinin artmasına ve sağlık politikalarının geliştirilmesine rehberlik eder. ${ }^{6}$ Bu nedenle sunulan çalışma; hemşirelik bölümü öğrencilerinin klinik uygulamalar sırasında el hijyeni sağlama, eldiven kullanımına yönelik bilgi düzeyleri ve alışkanlıklarının belirlenerek, elde edilecek verilerin sınıf, yaş, cinsiyet ve bilgi alma değişkenleriyle ilişkisinin saptanması ve bilgi eksikliklerinin giderilmesine yönelik önerilerinin sunulması amacıyla yapılmıştır. Hastane enfeksiyonları ve izolasyon yöntemleri oldukça önemli olan ve güncelliğini hiçbir zaman kaybetmeyen bir konu olduğu için, konuyla ilişkin tanımlayııı çalışmalar faydalı olabilir. Geleceğin sağlık çalışanı adayı olan hemşirelik öğrencilerinde hastane enfeksiyonlarının önlenmesinde en etkili izolasyon yöntemlerinden birisi olan eldiven kullanımı alışkanlıklarının gerçekçi bir yaklaşımla belirlenmesinin, eldiven kullanım alışkanlıklarındaki yanlış uygulamaların giderilmesine ya da en aza indirgenmesine katkı sağlaması muhtemeldir. Bu nedenle hemşirelik öğrencilerinin, el hiyjeni ve eldiven kullanma alışkanlıklarının belirlenmesinin çalışma alanına ve literatüre olumlu katkı sağlaması hedeflenmektedir.

\section{Gereç ve Yöntemler}

\section{Araştırmanın tipi}

Araştırma tanımlayıcı niteliktedir. 


\section{Araştırmanın yapıldığı tarih ve yer}

Araştırma 1-30 Haziran 2018 tarihlerinde bir devlet üniversitesinin sağlık bilimleri fakültesinde yürütülmüştür.

\section{Araştırma örneklemi}

Araştırma; örneklem içinden seçilen nesnenin, araştırmacının yargılarıyla belirlendiği ve tesadüfî olmayan yöntem olarak tanımlanan "Kolayda Örnekleme Yöntemi" ile gerçekleştirilmiştir. ${ }^{13-16}$ Araştırmanın örneklemi, bir devlet üniversitesinin sağlık bilimleri fakültesi hemşirelik bölümü birinci ve ikinci sınıf öğrencileridir. Araştırmanın yapıldığı tarihlerde üçüncü ve dördüncü sınıf öğrencileri klinik uygulamada oldukları için çalışmaya dahil edilmemişlerdir. Hemşirelik bölümüne kayıtlı olan birinci sınıfta 90 , ikinci sınıfta 93 öğrencinin tamamına ulaşıması hedeflenmesine rağmen; bazı öğrencilerin devamsız olması, bazılarının katılmak istememesi nedeniyle birinci sınıftan 70, ikinci sınıftan 71 olmak üzere 141 öğrenciye ulaşılmıştır. Çalışmaya katılım oranı \%77'dir. Çalışmamızın örneklem büyüklüğü yeterli sayıda olup, literatürdeki benzer çalışmalarla uyumludur. ${ }^{17-19}$

\section{Veri toplama aracı ve verilerin toplanması}

Veriler, araştırmacı tarafından literatür bilgisi dikkate alınarak hazırlanan anket formuyla toplanmıştır. ${ }^{1-6,20}$ Söz konusu anket; iki bölümde toplam 75 maddeden oluşmaktadır. İlk bölüm katılımcıların sosyo-demografik özelliklerinin belirlenmesinin amaçlandığı dört maddeden, ikinci bölüm el hijyeni bilgisi ve eldiven kullanma alışkanlıklarının belirlenmesine yönelik olan sistematize edilmiş evet-hayır, çoklu likert ve açık uçlu soru formatındaki 71 maddeden oluşmaktadır. Anketin uygulanma süresi ortalama 10-15 dakika olup, katılım gönüllülük esasıyla sağlanmıştır. Anket formunda hemşirelik öğrencilerinin el hijyeni bilgisi ve eldiven kullanma alışkanlıklarının belirlenmesine yönelik maddeler yer aldığı için, sunulan çalışma hemşirelik öğrencilerinin eldiven kullanma alışkanlıklarının belirlenmesini amaçlayan maddelerin değerlendirildiği verileri kapsamaktadır.

\section{Etik boyut}

Araştırma için; katılımcıların sözlü onamı, araştırmacının bağı bulunduğu kurumdan kurum izni ve Karamanoğlu Mehmetbey Üniversitesi Sağlık Bilimleri Fakültesi Girişimsel Olmayan Klinik Araştırmalar Etik Kurulu'ndan izin alınmıştır (Karar No: 06-16, Karar tarihi: 30/05/2018). Anket formunda öğrenci isimlerine yer verilmemiştir.

\section{Verilerin değerlendirilmesi}

Veriler, lisanslı 32 bit edition Release SPSS 21.0.0.0 paket programına aktarılmış; tanımlayıcı analizler için frekans, yüzdelik, ortalama ve standart sapma, gruplar arasındaki farklılıkların belirlenmesi amacıyla Ki-kare testi yapılmış ve $p<0,05$ anlamlı kabul edilmiştir. Örneklem yeterliliğinin ölçümü için Kaiser-Meyer-Olkin (KMO) testi yapılmıştır. Güvenilirlik analizi için Cronbach alfa güvenilirlik katsayısı hesaplanmıştır. ${ }^{21,22}$ Elde edilen veriler araştırmanın amacı dışında kullanılmamıştır.

\section{Kısıtlılıklar}

Araştırma katılımcı cevaplarıyla sınırıdır. Çalışmanın birinci ve ikinci sınıf öğrencileriyle gerçekleştirilmesi, devamsız ve katılmak istemeyen öğrencilere ulaşılamamış olunması çalışmanın kısıtııığını oluşturmaktadır. 


\section{Bulgular}

Çalışmamıza; 116 'sı kadın $(\% 82,3)$ ve $25^{\prime}$ i erkek $(\% 17,7)$ olmak üzere toplam 141 öğrenci katılmış olup katılımcıların \%11'inin 18 yaşında, \% 79'unun 19-21 yaş aralığında (Min 18-Max 25) olduğu belirlenmiştir (Şekil 1).
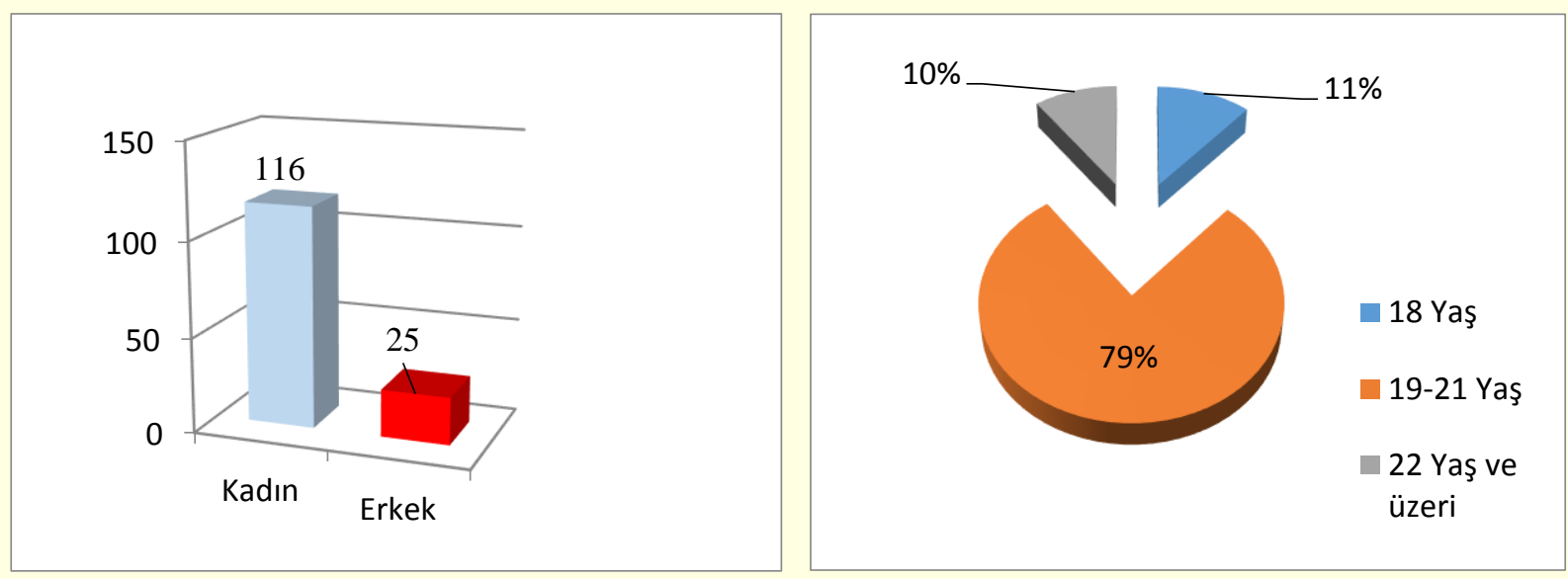

Şekil 1. Öğrencilerin cinsiyetleri ve yaş aralıkları

Katılımcıların \%72,3'ünün önceden hijyen eğitimi aldığı, eğitim alan öğrencilerin \%87,1'inin ikinci sınıf ve \%64'ünün kadın öğrecilerden oluştuğu, eğitim kaynağının büyük oranda üniversite-lise dersleri olduğu belirlenmiştir (Tablo 1). Hijyen eğitim alma değişkeni ile sınıf değişkeni ( $p: 0,03)$ ve yaş değişkeni arasında ( $p$ : 0,01 ) ilişki belirlenmiştir. Önceden hijyen eğitimi alan katılımcıların, yaşları büyük olan ikinci sınıf öğrencileri olduğu saptanmıştır.

Tablo 1. Öğrencilerin hijyen eğitimi konusunda bilgi alma durumları ve bilgi alınan kaynaklar*

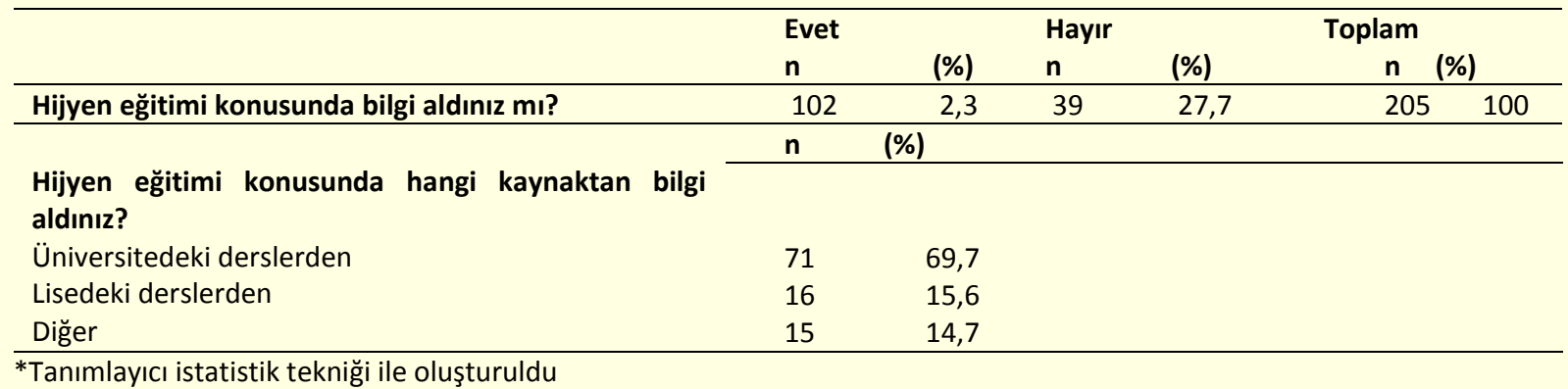

Örneklem yeterliliğinin belirlenmesi amacıyla, maddelerin faktör yüklerine bakılmış ve Kaiser-Meyer-Olkin (KMO) değeri: 0,75 olarak belirlenmiştir (Tablo 2). KMO değerinin 0,50'ten büyük, bire yakın olması faktör analizi için yeterlidir. ${ }^{23,24}$ Çalışmanın güvenilirliğinin belirlenmesi için Cronbach Alfa testi yapılmış ve Cronbach Alfa değeri: 0,65 olarak belirlenmiştir (Tablo 2). Cronbach Alfa değerinin bire yakın olması, anket formunun güvenilir olduğu anlamına gelmektedir. ${ }^{21,22}$ Çalışmada kullanılan anketin geçerlilik ve güvenilirlik kriterlerine sahip olduğu söylenebilir. ${ }^{21-24}$ 
Tablo 2. Örneklem yeterliliğinin ölçümü, küresellik testi ve anketin güvenilirlik analizi*

\begin{tabular}{lrl}
\hline Kaiser-Meyer-Olkin test değeri: & Ki-Kare: & 0,75 \\
Bartlett testi & df: & 2485,40 \\
& Sig: & 0,00 \\
& & 0,65 \\
Cronbach alfa değeri: & & 71 \\
n= & & 71 \\
\hline
\end{tabular}

*Kaiser-Meyer-Olkin; KMO, Bartlett ve Cronbach alfa testi kullanılarak oluşturuldu.

"Eldiven kullanmak ya da değiştirmek el yıkama gereksiniminin yerini tutar" önermesine katılım oranının $\% 37,6$ olduğu, önermeye katılım ile sınıf değişkeni arasında ilişki belirlenirken $(p=0,02)$, yaş, cinsiyet ve eğitim değişkenleri arasında ilişki belirlenmemiştir ( $p=0,18 ; p=0,83 ; p=0,32$ ). "Eldiven kullanılarak yapılan bir işlemden sonra el yıkanmalıdı" önermesine katıım oranının \%83,7 olduğu, önermeye katılım ile sınıf, yaş, cinsiyet ve eğitim değişkenleri arasında ilişki belirlenmemiştir ( $p=0,56 ; p=0,95 ; p=0,66 ; p=0,25)$. "Eldiven takmadan önce eller yıkanmalıdı" önermesine katııım oranının \%86,5 olduğu, önermeye katılım ile sınıf ve yaş değişkenleri arasında ilişki belirlenirken $(p=0,02 ; p=0,04)$, cinsiyet ve eğitim değişkenleriyle ilişki belirlenmemiştir $(p=0,13 ; p=0,85)$.

"Eldiven çıkarıldıktan sonra eller yıkanmalıdır" önermesine katılım oranının \%96,5 olduğu, önermeye katılım ile cinsiyet değişkeni arasında ilişki belirlenirken $(p=0,01)$, sınıf, yaş ve eğitim değişkenleriyle ilişki belirlenmemiştir ( $p=0,26 ; p=0,36 ; p=0,58)$. "Eldiven kullanımı hastalar arası bulaşıcılığı engeller" önermesine katılım oranının \%94,3 olduğu, önermeye katııım ile sınıf ve cinsiyet değişkenleri arasında ilişki belirlenirken ( $p=0,01 ; p=0,01)$, yaş ve eğitim değişkenleriyle ilişki belirlenmemiştir $(p=0,19 ; p=0,79)$ (Tablo 3).

Tablo 3. Değişkenler ile eldiven kullanımına ilişkin bazı önermeler arasındaki ilişki*

\begin{tabular}{|c|c|c|c|c|c|c|c|}
\hline Önerme & Değişken & & $\mathrm{n}$ & Ortalama & $\begin{array}{l}\text { Standart } \\
\text { Sapma }\end{array}$ & $F$ & $p$ \\
\hline \multirow{9}{*}{$\begin{array}{l}\text { Eldiven kullanmak ya da değiştirmek el } \\
\text { yıkama gereksiniminin yerini tutar. }\end{array}$} & \multirow[b]{2}{*}{ Sinif } & 1. sınıf & 70 & 1,695 & 0,608 & 4,874 & 0,02 \\
\hline & & 2. $\sin I f$ & 71 & 1,715 & 0,505 & & \\
\hline & \multirow{3}{*}{ Yaş } & 18 yaş & 16 & 1,795 & 0,611 & 1,626 & 0,18 \\
\hline & & $19-21$ yaş & 111 & 1,666 & 0,548 & & \\
\hline & & 22 yaş ve üzeri & 14 & 1,783 & 0,555 & & \\
\hline & \multirow[t]{2}{*}{ Cinsiyet } & Kadın & 116 & 1,717 & 0,538 & 0,186 & 0,83 \\
\hline & & Erkek & 25 & 1,692 & 0,672 & & \\
\hline & \multirow{2}{*}{$\begin{array}{l}\text { Eğitim } \\
\text { durumu }\end{array}$} & Evet & 102 & 1,728 & 0,540 & 1,142 & 0,32 \\
\hline & & Hayır & 39 & 1,666 & 0,627 & & \\
\hline \multirow{9}{*}{$\begin{array}{l}\text { Eldiven kullanılarak yapılan bir işlemden } \\
\text { sonra el yıkanmalıdır }\end{array}$} & \multirow[b]{2}{*}{ Sinıf } & 1. sınıf & 70 & 1,233 & 0,514 & 0,683 & 0,56 \\
\hline & & 2. sınıf & 71 & 1,200 & 0,474 & & \\
\hline & \multirow{3}{*}{ Yaş } & 18 yaş & 16 & 1,244 & 0,521 & 0,109 & 0,95 \\
\hline & & $19-21$ yaş & 111 & 1,213 & 0,484 & & \\
\hline & & 22 yaş ve üzeri & 14 & 1,229 & 0,511 & & \\
\hline & \multirow[b]{2}{*}{ Cinsiyet } & Kadın & 116 & 1,215 & 0,482 & 0,416 & 0,66 \\
\hline & & Erkek & 25 & 1,250 & 0,555 & & \\
\hline & \multirow{2}{*}{$\begin{array}{l}\text { Eğitim } \\
\text { durumu }\end{array}$} & Evet & 102 & 1,199 & 0,468 & 1,378 & 0,25 \\
\hline & & Hayır & 39 & 1,305 & 0,572 & & \\
\hline \multirow{9}{*}{ Eldiven takmadan önce eller yıkanmalıdır } & \multirow[b]{2}{*}{ Sinıf } & 1. sınıf & 70 & 1,232 & 0,541 & 4,320 & 0,02 \\
\hline & & 2. sınıf & 71 & 1,299 & 0,503 & & \\
\hline & \multirow{3}{*}{ Yaş } & 18 yaş & 16 & 1,163 & 0,514 & 2,643 & 0,04 \\
\hline & & $19-21$ yaş & 111 & 1,251 & 0,546 & & \\
\hline & & 22 yaş ve üzeri & 14 & 1,418 & 0,619 & & \\
\hline & \multirow[b]{2}{*}{ Cinsiyet } & Kadın & 116 & 1,258 & 0,550 & 1,99 & 0,13 \\
\hline & & Erkek & 25 & 1,326 & 0,584 & & \\
\hline & \multirow{2}{*}{$\begin{array}{l}\text { Eğitim } \\
\text { durumu }\end{array}$} & Evet & 102 & 1,271 & 0,555 & 0,155 & 0,85 \\
\hline & & Hayır & 39 & 1,291 & 0,591 & & \\
\hline
\end{tabular}




\begin{tabular}{|c|c|c|c|c|c|c|c|}
\hline \multirow{9}{*}{$\begin{array}{l}\text { Eldiven çıkarıldıktan sonra eller } \\
\text { yıkanmalıdır }\end{array}$} & \multirow[b]{2}{*}{ Sinif } & 1. sınıf & 70 & 1,124 & 0,440 & \multirow[t]{2}{*}{1,322} & \multirow[t]{2}{*}{0,26} \\
\hline & & 2. sinıf & 71 & 1,007 & 0,341 & & \\
\hline & \multirow{3}{*}{ Yaş } & 18 yaş & 16 & 1,142 & 0,500 & \multirow[t]{3}{*}{1,066} & \multirow[t]{3}{*}{0,36} \\
\hline & & $19-21$ yaş & 111 & 1,065 & 0,307 & & \\
\hline & & 22 yaş ve üzeri & 14 & 1,148 & 0,515 & & \\
\hline & & Kadın & 116 & 1,058 & 0,308 & 10,740 & 0,00 \\
\hline & Cinsiyet & Erkek & 25 & 1,250 & 0,622 & & \\
\hline & \multirow{2}{*}{$\begin{array}{l}\text { Eğitim } \\
\text { durumu }\end{array}$} & Evet & 102 & 1,084 & 1,359 & \multirow[t]{2}{*}{0,535} & \multirow[t]{2}{*}{0,58} \\
\hline & & Hayır & 39 & 1,138 & 1,511 & & \\
\hline \multirow{9}{*}{$\begin{array}{l}\text { Eldiven kullanımı hastalar arası bulaşıcılığı } \\
\text { engeller }\end{array}$} & \multirow[b]{2}{*}{ Sinif } & 1. $\sin I f$ & 70 & 1,125 & 0,447 & \multirow[t]{2}{*}{5,290} & \multirow[t]{2}{*}{0,01} \\
\hline & & 2. sınıf & 71 & 1,157 & 0,336 & & \\
\hline & \multirow{3}{*}{ Yaş } & 18 yaş & 16 & 1,142 & 0,501 & \multirow[t]{3}{*}{1,573} & \multirow[t]{3}{*}{0,19} \\
\hline & & $19-21$ yaş & 111 & 1,114 & 0,396 & & \\
\hline & & 22 yaş ve üzeri & 14 & 1,243 & 0,544 & & \\
\hline & \multirow[b]{2}{*}{ Cinsiyet } & Kadın & 116 & 1,129 & 0,410 & \multirow[t]{2}{*}{4,669} & \multirow[t]{2}{*}{0,01} \\
\hline & & Erkek & 25 & 1,230 & 0,581 & & \\
\hline & \multirow{2}{*}{$\begin{array}{l}\text { Eğitim } \\
\text { durumu }\end{array}$} & Evet & 102 & 1,144 & 0,428 & \multirow[t]{2}{*}{0,232} & \multirow[t]{2}{*}{0,79} \\
\hline & & Hayır & 39 & 1,180 & 0,539 & & \\
\hline
\end{tabular}

*p değerleri Ki-kare testiyle elde edildi.

"Eldiven kullanımı bizden hastalara doğru olabilecek bulaşıcılığı engeller" önermesine katılım oranının \%95 olduğu, önermeye katılım ile eğitim değişkeni arasında ilişki belirlenirken $(p=0,01)$, sınıf, yaş ve cinsiyet değişkenleri arasında ilişki belirlenmemiştir $(p=0,43 ; p=0,62 ; p=0,35)$. "Eldiven kullanımı hastalardan bize karşı olabilecek bulaşıcılı̆ı̆ engeller" önermesine katılım oranının \%93,6 olduğu, önermeye katılım ile cinsiyet değişkeni arasında ilişki belirlenirken $(p=0,01)$, sınıf, yaş ve eğitim değişkenlerle ilişki belirlenmemiştir $(p=0,41 ; p=0,09 ; p=0,27)$. "Eldiven takmadan önce ve eldiven kullandıktan sonra eller yıkanmalıdır" önermesine katılım oranının \% 86,6 olduğu, önermeye katılım ile sınıf, yaş, cinsiyet ve eğitim değişkenleri arasında ilişki belirlenmemiştir $(p=0,41 ; p=0,09 ; p=0,27 ; p=0,56)$. "Eldiven üzerine antiseptik uygulanırsa hijyen sağlanır, eldiven değiştirmeye gerek yoktur" önermesine katılım oranının \%14,2 olduğu, önermeye katılım ile sınıf, yaş, cinsiyet ve eğitim değişkenleri arasında ilişki belirlenmemiştir $(p=0,14 ; p=0,50 ; p=0,67$; $p=0,75)$.

"Her hastada eldiven değiştirtmeli ve el hijyeni sağlanmalıdır" önermesine katılım oranının \%92,9 olduğu, önermeye katılım ile cinsiyet değişkeni arasında ilişki belirlenirken $(p=0,01)$, sınıf, yaş, ve eğitim değişkenleri arasında ilişki belirlenmemiştir $(p=0,41 ; p=0,05 ; p=0,63)$. "Aynı hastada kirli bölgeden temiz bölgeye geçerken eldiven değiştirilmelidir" önermesine katılım oranının \%85,8 olduğu, önermeye katılım ile cinsiyet ve eğitim değişkenleri arasında ilişki belirlenirken $(p=0,01 ; p=0,01)$, sını ve yaş değişkenleri arasında ilişki belirlenmemiştir $(p=0,25 ; p=0,20)$. "Eldiven yıkandıktan sonra tekrar kullanılabilir" önermesine katılım oranının \%15,6 olduğu, önermeye katılımla cinsiyet değişkeni arasında anlamlı ilişki belirlenirken ( $p=0,01)$, sınıf, yaş ve eğitim değişkenleri arasında ilişki belirlenmemiştir ( $p=0,90 ; p=0,68 ; p=0,37)$ (Tablo 4).

Katılımcıların \%37,6'sı eldiven kullanmanın yada değiştirmenin el yıkama gereksiniminin yerini tutacağını, \%15,6'sı eldivenin yıkandıktan sonra tekrar kullanılabileceğini, \%14,2'si eldiven üzerine antiseptik uygulanırsa hijyen sağlanacağını için eldiven değiştirmeye gerek olmadığını ifade etmişlerdir.

"Hem hastayı hem de kendimizi korumada en güvenli yöntem hangisidir?" sorusuna; \%56,7 el yıkama, \%39,0 eldiven kullanma ve \%4,3 alkol bazlı el antiseptiği kullanma cevaplarının verildiği tespit edilmiştir. Öğrencilerimizin el yıkama ve eldiven kullanma tercihlerinin cinsiyet $(p<0,001)$ değişkeniyle ilişkili olduğu; sınıf $(p=0,17)$, yaş $(p=0,43)$ ve bilgi alma $(p=0,59)$ değişkenleriyle ilişkili olmadığı belirlenmemiştir (Tablo 5). 
Tablo 4. Değişkenler ile eldiven kullanımına ilişkin bazı önermeler arasındaki ilişki*

\begin{tabular}{|c|c|c|c|c|c|c|c|}
\hline Önerme & Değişken & & n & Ortalama & $\begin{array}{l}\text { Standart } \\
\text { Sapma }\end{array}$ & $\mathbf{F}$ & $p$ \\
\hline \multirow{9}{*}{$\begin{array}{l}\text { Eldiven kullanımı bizden hastalara doğru } \\
\text { olabilecek bulaşıcılığı engeller }\end{array}$} & & 1. sınıf & 70 & 1,241 & 1,133 & 0,913 & 0,43 \\
\hline & Sinıf & 2. sinıf & 71 & 1,320 & 1,432 & & \\
\hline & & 18 yaş & 16 & 1,081 & 0,343 & 0,583 & 0,62 \\
\hline & Yaş & $19-21$ yaş & 111 & 1,092 & 0,761 & & \\
\hline & & 22 yaş ve üzeri & 14 & 1,202 & 0,522 & & \\
\hline & & Kadın & 116 & 1,129 & 0,410 & 4,669 & 0,01 \\
\hline & Cinsiyet & Erkek & 25 & 1,230 & 0,581 & & \\
\hline & Eğitim alma & Evet & 102 & 1,110 & 0,712 & 4,246 & 0,01 \\
\hline & durumu & Hayır & 39 & 1,111 & 0,358 & & \\
\hline \multirow{9}{*}{$\begin{array}{l}\text { Eldiven kullanımı hastalardan bize karşı } \\
\text { olabilecek bulaşıcılığı engeller }\end{array}$} & & 1. sınıf & 70 & 1,036 & 0,241 & 0,958 & 0,41 \\
\hline & Sinıf & 2. sınıf & 71 & 1,046 & 0,211 & & \\
\hline & & 18 yaş & 16 & 1,081 & 0,343 & 2,109 & 0,09 \\
\hline & Yaş & 19-21 yaş & 111 & 1,032 & 0,178 & & \\
\hline & & 22 yaş ve üzeri & 14 & 1,082 & 0,320 & & \\
\hline & & Kadın & 116 & 1,035 & 0,184 & 4,823 & 0,00 \\
\hline & Cinsiyet & Erkek & 25 & 1,153 & 0,459 & & \\
\hline & Eğitim & Evet & 102 & 1,042 & 0,221 & 1,300 & 0,27 \\
\hline & durumu & Hayır & 39 & 1,097 & 0,342 & & \\
\hline \multirow{9}{*}{$\begin{array}{l}\text { Eldiven üzerine antiseptik uygulanırsa } \\
\text { hijyen sağlanır, eldiven değiştirmeye gerek } \\
\text { yoktur }\end{array}$} & & 1. sinıf & 70 & 1,942 & 0,428 & 1,805 & 0,14 \\
\hline & Sinıf & 2. sinıf & 71 & 1,887 & 0,320 & & \\
\hline & & 18 yaş & 16 & 1,979 & 0,520 & 0,786 & 0,50 \\
\hline & Yaş & 19-21 yaş & 111 & 1,939 & 0,350 & & \\
\hline & & 22 yaş ve üzeri & 14 & 1,986 & 0,453 & & \\
\hline & & Kadın & 116 & 1,954 & 0,372 & 0,401 & 0,67 \\
\hline & Cinsiyet & Erkek & 25 & 2,011 & 0,560 & & \\
\hline & Eğitim & Evet & 102 & 1,944 & 0,392 & 0,286 & 0,75 \\
\hline & durumu & Hayır & 39 & 1,986 & 0,459 & & \\
\hline \multirow{9}{*}{$\begin{array}{l}\text { Her hastada eldiven değiştirilmeli ve el } \\
\text { hijyeni sağlanmalıdır }\end{array}$} & & 1. sınıf & 70 & 1,102 & 0,351 & 0,964 & 0,41 \\
\hline & Sinıf & 2. sinif & 71 & 1,044 & 0,261 & & \\
\hline & & 18 yaş & 16 & 1,979 & 0,520 & 0,786 & 0,50 \\
\hline & Yaş & 19-21 yaş & 111 & 1,939 & 0,350 & & \\
\hline & & 22 yaş ve üzeri & 14 & 1,986 & 0,453 & & \\
\hline & & Kadın & 116 & 1,054 & 0,260 & 6,001 & 0,00 \\
\hline & Cinsiyet & Erkek & 25 & 1,192 & 0,486 & & \\
\hline & Eğitim & Evet & 102 & 1,072 & 0,318 & 0,450 & 0,63 \\
\hline & durumu & Hayır & 39 & 1,111 & 0,316 & & \\
\hline \multirow{9}{*}{$\begin{array}{l}\text { Aynı hastada kirli bölgeden temiz bölgeye } \\
\text { geçerken eldiven değiştirilmelidir }\end{array}$} & & 1. sınıf & 70 & 1,195 & 0,456 & 1,356 & 0,25 \\
\hline & Sinif & 2. sinıf & 71 & 1,093 & 0,394 & & \\
\hline & & 18 yaş & 16 & 1,285 & 0,540 & 1,550 & 0,20 \\
\hline & Yaş & 19-21 yaş & 111 & 1,136 & 0,442 & & \\
\hline & & 22 yaş ve üzeri & 14 & 1,148 & 0,427 & & \\
\hline & & Kadın & 116 & 1,105 & 0,366 & 13,691 & 0,00 \\
\hline & Cinsiyet & Erkek & 25 & 1,403 & 0,693 & & \\
\hline & Eğitim & Evet & 102 & 1,161 & 0,451 & 8,642 & 0,00 \\
\hline & durumu & Hayır & 39 & 1,138 & 0,421 & & \\
\hline \multirow{9}{*}{$\begin{array}{l}\text { Eldiven yıkandıktan sonra tekrar } \\
\text { kullanılabilir }\end{array}$} & & 1. sinıf & 70 & 1,902 & 0,337 & 0,191 & 0,90 \\
\hline & Sinıf & 2. sinif & 71 & 1,895 & 0,343 & & \\
\hline & & 18 yaş & 16 & 1,857 & 0,353 & 0,490 & 0,68 \\
\hline & Yaş & 19-21 yaş & 111 & 1,896 & 0,339 & & \\
\hline & & 22 yaş ve üzeri & 14 & 1,891 & 0,455 & & \\
\hline & & Kadın & 116 & 1,917 & 0,327 & 5,656 & 0,00 \\
\hline & Cinsiyet & Erkek & 25 & 1,730 & 0,528 & & \\
\hline & Eğitim & Evet & 102 & 1,902 & 0,361 & 0,992 & 0,37 \\
\hline & durumu & Hayır & 39 & 1,833 & 0,411 & & \\
\hline
\end{tabular}

\footnotetext{
* p değerleri Ki-kare testiyle elde edildi.
} 
Tablo 5. Öğrencilerin el yıkama ve eldiven kullanma tercihleriyle değişkenler arası ilişkiler

\begin{tabular}{|c|c|c|c|c|c|c|}
\hline & Grup & $\mathbf{n}$ & Ortalama & $\begin{array}{l}\text { Standart } \\
\text { Sapma }\end{array}$ & $\mathbf{F}$ & $\mathbf{p}$ \\
\hline \multirow{9}{*}{ El yıkama ve eldiven kullanma tercihi } & 1. sınıf & 70 & 2,085 & 0,651 & \multirow[t]{2}{*}{1,738} & \multirow[t]{2}{*}{0,17} \\
\hline & 2. $\sin i f$ & 71 & 1,642 & 0,614 & & \\
\hline & 18 yaş & 16 & 2,102 & 0,620 & \multirow[t]{3}{*}{2,839} & \multirow[t]{3}{*}{0,80} \\
\hline & $19-21$ yaş & 111 & 1,553 & 0,643 & & \\
\hline & 22 yaş ve üzeri & 14 & 1,729 & 0,763 & & \\
\hline & Kadın & 116 & 1,662 & 0,672 & \multirow[t]{2}{*}{18,988} & \multirow[t]{2}{*}{0,00} \\
\hline & Erkek & 25 & 1,754 & 0,789 & & \\
\hline & Eğitim alan & 102 & 1,690 & 0,697 & \multirow[t]{2}{*}{0,515} & \multirow[t]{2}{*}{0,59} \\
\hline & Eğitim almayan & 39 & 1,660 & 0,692 & & \\
\hline
\end{tabular}

\section{Tartışma}

Toplumsal bir sağlık sorunu olan hastane enfeksiyonlarının önlenmesinde, hijyen kurallarının uygulanması birinci derecede önemlidir. Hijyen kurallarının doğru ve etkin uygulanmasında eğitimin önemi tartışmasızdır. Çalışmamızda; önceden hijyen kuralları eğitimi alan katııımıların oranı benzer çalışmalardan yüksektir. ${ }^{25,26}$ Hijyen konusunda sağlık çalışanlarının yaptığı yanlış uygulamalar ancak eğitim yoluyla düzeltilebileceği için geleceğin sağlık çalışanı adaylarının eğitimine daha fazla önem verilmelidir.

Hijyen konusunda eğitim almak kadar, eğitimle elde edilen kazanımların alışkanlık haline dönüşmesi önemli ve gereklidir. ${ }^{1,3,7}$ Hastane enfeksiyonu riskine karşı, etkinliği kanıtlanmış standart önlemlerden olan eldiven kullanma alışkanlığı; hem genel hijyen kurallarının bir gerekliliği, hem de hastanın moralini yükselten basit ama etkili bir uygulamadır. ${ }^{3}$ Öğrencilerimizin iki hasta bakımı arasında eldiven değiştirme alışkanlıklarının yüksek olduğu belirlenmiştir. Literatürde, hemşirelerin \%98,2'sinin hastalar arasında eldiven değiştirdikleri diğer bir çalışmada; üniversite hastanesi öğrencilerinin \%94,6'sının her hastadan sonra, \%74,2'sinin aynı hastada kirli bölgeden temiz bölgeye geçerken eldiven değiştirdikleri ifade edilmiştir. ${ }^{27,28}$ Öğrencilerimizin eldiven kullanım alışkanlıklarının benzer çalışmalar ile uyumlu olduğu, söylenebilir. Bu durum, öğrencilerimizin büyük bölümünün konu hakkında doğru bilgi sahibi oldukları ve kazanımlarını alışkanlık haline dönüştürdükleri şeklinde yorumlanmıştır.

El hijyeninin sağlanmasında, eldiven kullanımı en etkili izolasyon yöntemidir. Sağılı çalışanlarının izolasyon yöntemlerine uyum düzeylerinin artması hastane enfeksiyonlarının önlenmesinde etkilidir. ${ }^{6}$ Öğrencilerimizin büyük bölümünün izolasyon yöntemi olarak eldiveni tercih ettikleri belirlenmiştir. Literatürde izolasyon yöntemi olarak eldiveni tercih eden hemşirelik öğrencilerinin oranları; \%35,1, \%93,2 ve \%84 olarak belirtilmiştir. ${ }^{25,29,30}$ Hemşirelerin $\% 62,8^{\prime}$ i eldiven ve maskeyi, Sağlık Hizmetleri Meslek Yüksekokulu öğrencilerinin \%72,2'si eldiveni tercih etmektedir. ${ }^{27,31}$ Öğrencilerimiz eldiven kullanımını izolasyon yöntemleri arasında ilk sırada tercih etmekte ve bu durum literatürle uyumluluk sergilemektedir.

Tam korunma; güvenilir bir izolasyon yöntemi olan eldivenin, standartlara uygun ve doğru uygulamalar dahilinde kullanılmasıyla mümkündür. ${ }^{6}$. Literatürde "sağlık çalışanlarında eldivenin standartlara uygun kullanımı" konusunun araştırıldığı pek çok çalışma bulunmaktadır. Hemşirelerin \%89,4'ünün eldiveni doğru kullandığı, hemşirelik ve ebelik intörn öğrencilerinin izolasyon bilgilerinin yeterli olduğu, benzer şekilde çocuk bölümünde görev yapan hemşire ve hekimlerin izolasyon uyumunlarının iyi olduğu ifade edilmiştir. ${ }^{33-35}$ Buna karşın; hemşirelerin eldiveni standartlara uygun kullanmadıkları, yoğun bakım hemşirelerinde eldiveni doğru kullanma oranının $\% 37,8$ olduğu bildirilmiştir. ${ }^{33,36}$ Benzer şekilde üniversite hastanesi öğrencilerinin $\% 83,6$ 'sının eldivenin hatalı kullandığı, tıp bilimleri klinik öğrencilerinin izolasyon önlemleri hakkında bilgilerinin yetersiz, tutum ve uygulamalarının hatalı olduğu ifade edilmiştir. ${ }^{28,37}$ Sonuçlarımıza göre, öğrencilerimizin büyük bir bölümünün eldiveni standartlara uygun kullandığı belirlenmesine rağmen, hijyen 
konusunda yetersiz bilgiye sahip olan veya hatalı davranışta bulunan öğrencilerin olduğu açıktır. Kontamine elleriyle hizmet veren tek bir sağlık çalışanının onlarca kişiyi enfekte edebilme riski düşünüldüğünde; bilgi eksikliklerinin titizlikle belirlenmesi, güncel bilgiler ışığında giderilmesi, hatalı uygulamaların düzeltilmesi ve kontrolün özenle sağlanması gerektiği düşüncesindeyiz.

Eldiven kullanmak ya da değiştirmek, en etkili izolasyon yöntemi olmasına rağmen el yıkamanın yerini alamaz. El hijyeninin sağlanmasında en etkin önlem el yıkama olduğu için eldiven kullanarak yapılan her işlemin öncesinde ve sonrasında eller mutlaka yıkanmalıdır. ${ }^{7}$ Çalışmamızda öğrencilerimizin çok az bir bölümünün eldiven kullanmanın ya da değiştirmenin el yıkamanın yerine geçebileceğini belirttikleri, bununla birlite eldiven giymeden önce ve çıkardıktan sonra ellerin yıkanma oranının çok yüksek olduğu belirlenmiştir. Literatürdeki bir çalışmada; üniversite hastanesi öğrencilerinin eldiven giymenin el hijyeni sağlamada tek başına yeterli olduğunu düşündükleri ifade edilmiştir. ${ }^{28}$ Hemşirelerde ellerin yıkanma oranı; eldiven giyilmeden önce \%88,2 ve eldiven çıkarıldıktan sonra \%99,1 olarak; yoğun bakım ünitesinde görevli sağlık personelinde eldiven çıkarıldıktan sonra \%73 olarak ifade edilmiştir. ${ }^{27,32}$ Buna karşın; hemşirelerde en sık görülen yanlış davranışın; eldiven giymeden önce ellerin yıkanmaması olduğu bildirilmiştir. ${ }^{28}$ Benzer şekilde hemşirelerde eldiven çıkardıktan sonra el yıkama oranı \%14,9; yardımcı hastane personelinde eldiven giymeden önce $\% 10,7$ ve eldiven çıkardıktan sonra \%1,9 olarak bildirilmiştir. ${ }^{5,2}$ Öğrencilerimizin büyük bir bölümünün el yıkama oranlarının yüksek olduğu, el yıkamayı eldiven kullanma ile eşdeğer görmedikleri ve el yıkamayı alternatif uygulamalardan daha fazla tercih ettikleri belirlenmiştir. Bu açıdan bakıldığında öğrencilerimizin büyük bir bölümünde el hijyeni ve el yıkama uyumunun geliştiği söylenebilir.

Çalışmamızda, el hiyjeni ve eldiven kullanmayla cinsiyet değişkeni arasında kuvvetli ilişki belirlenmiş; kadınların el hijyeni ve eldiven kullanma alışkanlıklarının erkeklerden yüksek olduğu saptanmıştır. Bu durumun; katılımcıların büyük bir bölümünün kadın öğrencilerden oluşmasından kaynaklandığı düşünülmektedir. Çalışmamızla uyumlu olan bir çalışmada; kadın hemşirelik öğrencilerinin bilgi puan ortalamalarının, erkek öğrencilerden yüksek olduğu belirtilmiştir. ${ }^{38}$ Buna karşın; hemşirelik öğrencilerinde cinsiyet değişkeniyle el hijyeni ve eldiven kullanımı arasında anlamlı bir farkın olmadığı bildirilmiştir. ${ }^{6,39}$ Sonuçlarımızın literatürdeki bazı çalışmalarla uyumlu olmamasının; çalışmamıza üçüncü ve dördüncü sınıf öğrencilerinin dahil edilmemesinden, öğrencilerimizin sorulara kısıtlı yanıt vermelerinden, çalışmalardaki katılımcı sayısının, yaş ve cinsiyet gibi değişkenlerin farkıı olmasından kaynaklandığı düşünülmektedir.

\section{Sonuç ve Öneriler}

Eğitim; sağlık çalışanlarında el hijyenin sağlanması ve uyumun artırımasında, eldiven kullanımındaki yanlış uygulamalarının giderilmesinde ve sonuçta hastane enfeksiyonlarının önlenmesinde önemli bir etmendir. Bu amaçla, öğrencilerde kalıcı öğrenmenin sağlanıp doğru davranışların alışkanlık haline gelebilmesi için birinci sınıftan başlanarak derslerde el hijyeni, eldivenin doğru ve etkin kullanımına yönelik eğitimlerin verilmesinin faydalı olabileceği düşüncesindeyiz. Eğitim süreciyle paralel olarak staj sürelerinin artırılması ve stajlarda uygulamaların titizlikle takip edilmesi önerilir.

\section{Bilgi}

Anketimize katılarak soruları içtenlikle yanıtlayan öğrencilerimize teşekkür ederiz. Çıkar çatışması yoktur.

Araştırma 5-6 Nisan 2019'de İzmir'de düzenlenen Erasmus Uluslararası Akademik Araştırmalar Sempozyumu'nda sözel bildiri olarak sunulmuştur. 


\section{Etik Onay}

Karamanoğlu Mehmetbey Üniversitesi Sağlık Bilimleri Fakültesi Girişimsel Olmayan Klinik Araştırmalar Etik Kurulu (Karar No: 06-16, Karar tarihi: 30/05/2018)

\section{Kaynaklar}

1. Demir N ve ark. Sağıık çalışanlarının el hijyeni hakkında bilgi düzeyi ve el hijyenine uyumu. Nobel Med 2013;9(3):104-9.

2. Akça M, Keşaplı M. Acil serviste el yıkama alışkanlıkları ve ülkemizdeki sağlık politikalarının bu alışkanlık üzerine etkileri. Van Tıp Derg 2016;23(2):176-82.

3. İnfal S, Şahin T. Bir üniversite hastanesindeki yardımcı personelin hastane enfeksiyonları ile ilgili bilgi ve tutumlarının değerlendirilmesi. Turk Hij Den Biyol Derg 2016;73(1-1):39-44.

4. Çelik S, Koçaşlı S. Hygienic hand washing among nursing students in Turkey. Appl Nurs Res 2008;21:207-11.

5. Karaoğlu M, Akın S. Hemşirelerin el yıkama alışkanlıklarına ilişkin görüşleri ve el hijyeni uyum oranlarının değerlendirilmesi. Hemşirelikte Eğitim ve Araştırma Derg 2019;16(1):33-40.

6. Karaahmetoğlu G, Softa H. Hemşirelik öğrencilerinin eldiven kullanımına yönelik tutumlarının belirlenmesi. Düzce Üniversitesi Sağlık Bilimleri Enstitüsü Derg 2016;6(3): 168-72.

7. Şensoy E, Çakır M. Hemşire adayların el yıkama ve kişisel hijyen alışkanlıklarının değerlendirilmesi. İçinde: Karacagil Z, Anaz $E$, editörler. Sosyal Bilimlerde Güncel Tartışmalar İnsan Çalışmaları. Ankara: 1. Bilgin Kültür Sanat Yayınları; 2018, s:279-87.

8. Thomas-Copeland J. Do surgical personel really need to duble-glove? AORN Journal 2009;89(2):322-8.

9. Bulut S, Eşer I, Khorshid L. Sağlık personelinin eldiven kullanımına ilişkin hasta görüşlerinin incelenmesi. Electronic Journal of Vocational Colleges 2014;5:151-6.

10. Caballero M, Quirce S. Identification and practical management of latex allergy in occupational settings. Expert Rev Clin Immunol 2015;11(9):977-92.

11. Yıldırım S, Gerdan S. Hastane öncesi acil sağıık çalışanlarının iş sağlığı ve güvenliği kapsamındaki mesleki riskleri. Hastane Öncesi Derg 2017;2(1):37-49.

12. Erkan T. Hemşirelerin el yıkama davranışlarının değerlendirilmesi. Trakya Ün Sağlık Bil Enst 2010; Edirne.

13. Jafarov G, Yıldırım A. Hemşirelerin iş yaşamında ayrıcılığa ilişkin algılarının belirlenmesi. İnönü Üniversitesi Sağlık Hizmetleri Meslek Yüksek Okulu Derg 2020;8(3):749-62.

14. Erdem A. Mesleki özdeşleşmenin tükenmişliğe etkisinde iş yükü algısının aracilik rolü, hemşirelere yönelik bir araştırma. Gümüşhane Üniversitesi Sosyal Bilimler Enstitüsü Elektronik Derg 2020;11(10):89-103.

15. Benoot C, Hannes K, Bilsen J. The use of purposeful sampling in a qualitative evidence synthesis: A worked example on sexual adjustment to a cancer trajectory. BMC Med Res Methodol 2016;16(1):15-21.

16. Yağar F, Dökme S. Niteliksel araştırmaların planlanması: Araştırma soruları, örneklem seçimi, geçerlik ve güvenirlik. Gazi Sağlık Bilimleri Derg 2018;3(3):1-9.

17. Yurttaş A, Aras G. Hemşirelik öğrencilerinin kültürlerarası duyarlıııları ile empati düzeyleri arasindaki ilişki. Genel Sağlık Bilimleri Derg 2020;2(3):117-25.

18. Kırağ N, Güver Y. Türkiye ve Portekiz hemşirelik öğrencilerinin yaşam biçimi davranışları ve bağımlılık, depresyon düzeyleri. Sağlık Akademisyenleri Derg 2020;7(1):28-36.

19. Taşkiran N, ve ark. Son sınıf hemşirelik öğrencilerinin hemşirelik mesleğine, rollerine ve mesleğin geleceğine ilişkin görüşleri. Hastane Öncesi Derg 2020;5(1):43-56.

20. Karadağ M, Yıldırım N, İşeri P. El Hijyeni inanç ölçeği ve el hijyeni uygulamaları envanterinin geçerlilik ve güvenirliliği. Çukurova Üniversitesi Tıp Fakültesi Derg 2016;41(2):271-84.

21. Evcili F, Gölbaşı Z. Cinsel sağlık bilgi testi: Geliştirme, geçerlik ve güvenirlik çalışması. ACU Sağlık Bil Derg 2017;1(1):29-33.

22. Aydemir N, Yakın i, Aslan S. AIDS bilgi ve tutum ölçeklerinin geliştirilmesi ve psikometrik özelliklerinin sınanması. Psikoloji Çalışmaları 2018;38(1):73-93.

23. Balogun $\mathrm{J}$ et al. Evaluation of the content validity, internal consistency and stability of an instrument designed to assess the HIV/AIDS knowledge of university students. Health Education Journal 2010;23(3):400-7.

24. Najarkolaei R et al. Sexual behavioral abstine HIV/AIDS questionnaire: Validation study of an Iranian questionnaire. J Edu Health Promot 2014;3(10):1-5.

25. Artan O, Artan C, Bayka Z. Sağlık Hizmetleri Meslek Yüksekokulu Öğrencilerinin hastane enfeksiyonları ile ilgili bilgi düzeyleri. Düzce Üniversitesi Sağlık Bilimleri Enstitüsü Derg 2014;4(1):17-21.

26. Aktuğ N, ve ark. Bir üniversite hastanesi öğrencileri, araştırma görevlileri ve öğretim üyelerinin el hijyeni hakkındaki bilgi düzeyleri. Klimik Derg 2018;31(2):106-9. 
27. Çalışkan D, Akdur R. Ankara Üniversitesi Tıp Fakültesi Hastanesi'nde çalışan hemşirelerin kendi bildirimleri ile karşılaştıkları mesleki riskler. Ankara Üniversitesi Tıp Fakültesi Mecmuası 2001;54(2):135-42.

28. Demir N, ve ark. Bir üniversite hastanesi öğrencileri, araştırma görevlileri ve öğretim üyelerinin el hijyeni hakkındaki bilgi düzeyleri. Klimik Dergisi 2018;31(2):106-9.

29. Sohbet R ve ark. Hemşirelik öğrencilerin el yıkama ve hastane enfeksiyonlarına bakışı. 13. Ulusal Hemşirelik Öğrencileri Kongresi; s:132, 2014;1-3 Mayıs; Trabzon.

30. Atalan E ve ark. Hemşirelik öğrencilerinin kesici-delici tıbbi aletleri güvenli kullanıma yönelik tutumlarının belirlenmesi. 13. Ulusal Hemşirelik Öğrencileri Kongresi; s:27, 2014;1-3 Mayıs; Trabzon.

31. Ceylan G ve ark. Balıkesir Sağlık Yüksekokulu Hemşirelik öğrencilerinin mesleki risklere ilişkin değerlendirmeleri. 13. Ulusal Hemşirelik Öğrencileri Kongresi; s:302, 2014;1-3 Mayıs; Trabzon.

32. Toraman A, ve ark. Yoğun bakım ünitesinde sağık personelinin el yıkama alışkanlıkları. Yeni Tıp Derg 2009;26:85-9.

33. Doğu Ö, Tiryaki Ö. Yoğun bakım hemşirelerinin izolasyon uyumu ve eldiven kullanma tutumlarının iş doyumuyla ilişkisi. Yoğun Bakım Hemşireliği Derg 2017;21(1):16-22.

34. Doğu Ö, Karabay O. Hemşirelik ve ebelik intörn öğrencilerine enfeksiyon kontrol eğitim programı. Online Türk Sağlık Bilimleri Derg 2016;2(1):1-10.

35. Demir Z. Çocuklarla çalışan hemşire ve hekimlerin izolasyon önlemlerine uyumunun değerlendirilmesi. Mersin Üniversitesi, Sağlık Bilimleri Enstitüsü, 2014, Mersin.

36. Altun D, Alp E. Bir üniversite hastanesinde erişkin ve pediatri yoğun bakım ünitesinde çalışan sağlık personelinde el hijyenine uyum oranları ve doğru eldiven kullanımı. Hastane İnfeksiyonlar Derg 2008;12(1):1-30.

37. Azabadi A, et al. Assessment of knowledge, attitude and practice ofclinical students' of Yazd University of Medical Sciences toward Isolation Precaution. Internal Medicine and Medical Investigation Journal 2016;1(1):10-3.

38. Turan B, Mankan T, Türkben H. Hemşirelik öğrencilerinin el hijyenine ilişkin bilgi düzeyleri. Gümüşhane Üniversitesi Sağlık Bilimleri Derg 2017;6(3):65-70.

39. Mankan T, Kaşıkçı M. Hemşirelerin hastane enfeksiyonlarını önlemeye ilişkin bilgi düzeyleri. İnönü Üniversitesi Sağlık Bilimleri Derg 2015;4(1):11-6. 